\title{
Sedimentary pyrite as a trap of organic matter: preliminary results from large-framboid observation
}

\author{
Nicolas Tribovillard, Viviane Bout-Roumazeilles, Marion Delattre, Sandra Ventalon, and \\ Abderrahmane Bensadok \\ UMR 8187 LOG - Laboratoire d'Océanologie et de Géosciences, Univ. Lille, \\ CNRS, Univ. Littoral Côte d'Opale, IRD, 59000 Lille, France
}

Correspondence: Nicolas Tribovillard (nicolas.tribovillard@univ-lille.fr)

Received: 26 October 2021 - Accepted: 14 December 2021 - Published: 28 January 2022

\begin{abstract}
The Bancs Jumeaux Formation appears as a succession of limestone beds and marly interbeds, of Late Jurassic age (Tithonian), cropping out in the cliffs of the Boulonnais (French shore of the English Channel). This formation is enriched in pyrite present in abundance in the forms of framboids, polyframboids and other concretions of a relatively large size for sedimentary pyrite (a few tens to hundreds of micrometers). Previous works have shown that (poly)framboids appeared during early authigenesis in reducing microenvironments within dysoxic sediments. The question is whether, like what is observed for bacteria causing carbonate mineralization of their outer wall, sulfate-reducing bacteria could have been trapped (locked up) in pyrite "sarcophagi", induced by their own metabolism. In an attempt to provide answers, the large pyrites were extracted from the Bancs Jumeaux marls by physical separations and acid digests. Their analysis reveals the presence of organic matter in significant quantities. The typical morphology of certain polyframboids present in the studied samples suggests the early fossilization of bacterial colonies by pyrite. If pyrite appears to be a relatively significant trap for organic matter, then pyrite could represent an underevaluated component of the carbon cycle.
\end{abstract}

\section{Introduction}

Heterotrophic bacteria are known to sometimes induce the precipitation of authigenic minerals, as a consequence of their metabolism. Using organic substrates as electron suppliers of redox reactions, bacterial activity thus conditions various parameters of the interstitial waters within sediments, such as the $\mathrm{pH}$, Eh and alkalinity. See comprehensive syntheses by Megonigal et al. (2003), Braissant et al. (2003) and Burdige (2006, chaps. 7 and 16) as well as key papers such as those of Berner (1980), Jørgensen (1982), Hinrichs et al. (1999), Boetius et al. (2000) or Soetaert et al. (2007). The prominent two bio-induced products are calcite $\left(\mathrm{CaCO}_{3}\right)$ and pyrite $\left(\mathrm{FeS}_{2}\right)$.

The works of Castanier et al. (1999a, b) have shown, during controlled growth of bacteria in vivo, that calcifying bacteria can become calcified very quickly. This calcification can kill the bacteria by isolating them from the external milieu, but, in some cases, it has been observed that the bacteria remained alive inside their calcite "sarcophagus" or "cocoon" and that the essential exchanges with the external milieu were made possible by one or two orifices allowing the circulation of fluids. Here, the question is whether such a mechanism could exist with another authigenic mineral: pyrite. Could the sulfate-reducing bacteria, responsible for the precipitation of sedimentary pyrite, be mineralized, that is to say, pyritized, like other bacteria can be calcified? In an attempt to provide some answers to this question, this study focused on relatively large (poly)framboids (several tens to several hundreds of micrometers), easy to extract from marls rich in organic matter, belonging to the Bancs Jumeaux Formation (Fm.) of Tithonian age (Late Jurassic) and present in the cliffs of Boulonnais (north of France). A first study on the chemical composition of the framboids and polyframboids observed in the Bancs Jumeaux Fm. had underlined the early to very early character of the Bancs Jumeaux pyrite (Tribovillard et al., 2008). We therefore sought to isolate these (poly)framboids and observe them under a scanning electron microscope to see possible orifices in the pyrite microcrys- 
tals, and we analyzed the carbon content of these objects: the presence of $\mathrm{C}$ in pyrite can testify to the trapping of organic matter in the pyrite (trapping of bacterial biomass in bio-induced authigenic minerals).

The association of organic matter (OM) and pyrite framboids has been studied on numerous occasions, as evidenced by the syntheses of Rickard (2012, 2021). During the 20th century, some authors first wondered whether framboids could be the fossils of microorganisms, especially bacterial colonies. In a few words and as reported by Rickard (2021), there were supporters and opponents of this interpretation and the latter were more numerous. Closer to the central question of the present study, some authors have looked for traces of OM in, or associated with, framboids. The reasoning was that resistant biopolymers could have been incorporated into pyrite during its growth. Love and Amstutz (1966), Schieber (2002), and McLean et al. (2008) were thus able to extract organic molecules from framboids. Large et al. (2001) showed that such organic residues could be the result of the growth of framboids inside biofilms; Baumgartner et al. (2019) reached the same conclusion for Precambrian stromatolites. Wacey et al. (2015) were able to make an elementary mapping at a high resolution, highlighting the presence of OM. Gregory et al. (2019) also showed organic matter in pyrite framboids using nanoscale secondary ion mass spectrometry. It should be noted that both Wacey et al. (2015) and Gregory et al. (2019) found the OM to be between the microcrystals. Finally, Gregory et al. (2022) studied, using transmission electron microscopy at a high resolution, framboids formed under euxinic conditions; they observed lowdensity zones that could reflect the presence of OM. At the same time, some studies are interested in pyrite precipitation caused in vitro, induced by sulfate-reducing bacteria (e.g., Duverger et al., 2020, and references therein). Such studies show that pyrite precursors can impregnate the cell wall or the extracellular polymer substances (eps) secreted by bacteria. Notably, Picard et al. (2018) observed the precipitation of mackinawite and greigite triggered by the presence of (dead or live) cells of sulfate-reducing bacteria and their eps. However, in vitro studies focus on phenomena observed over short timescales, compatible with the requirements of laboratory work. These phenomena are not able to account for what happens during diagenesis. For instance, Picard et al. (2018) did not observe the formation of pyrite but that of mackinawite and greigite, which may be considered to be precursors of pyrite. In the present study, we observe the result of phenomena that occurred over 100 million years ago. We lack the intermediate observation scale, that of diagenesis. Here, we wish to determine whether bacteria could have been trapped in the pyrite cocoon, which would have caused precipitation by their metabolic by-products. Ideally, one should be able to dissolve the pyrite to reveal the possible presence of OM that could have been trapped inside. The problem is that nitric acid, which is effective in attacking pyrite, is also very effective in oxidizing and destroying labile OM (typically bacte- rial biomass). We therefore chose to study large framboids and polyframboids, which are easy to extract from the sediments. With such objects, it is easy to check whether they are coated with $\mathrm{OM}$, by observation with a scanning electron microscope (SEM).

\section{Materials and methods}

We took five rock samples of about $500 \mathrm{~g}$ each, in the marly interbeds of the Bancs Jumeaux Fm. (Fig. 1). These interbeds were already known to be very rich in large-size framboids and polyframboids (up to several hundred micrometers) as demonstrated by Tribovillard et al. (2008); the Bancs Jumeaux Fm. and its depositional conditions are detailed in that article. For the present study, the same protocol was used to extract (poly)framboids. In a few words, the marl samples were coarsely crushed down to centimeter-size lumps that were then decarbonated $(\mathrm{HCl})$. Through several rounds of rinsing, the suspended clay minerals were eliminated from the beakers, being removed with the supernatant. The operation was repeated at least 25 times. This treatment is considered to remove any adsorbed metal or organic molecule from the mineral surfaces and prevent any adsorption onto them. Pyrite surfaces are known to be able to capture in vitro ultrathin films made up with organic molecules (Himmel et al., 1996; Bebié and Schoonen, 2000), but Han et al. (2020) showed that the presence of acids could limit or hamper such adsorption. The residue then had to be digested with hydrochloric acid (HF) to solubilize quartz grains and other residual silicate minerals that were numerous, hampering observation. After these treatments, only clean pyrite particles and a few heavy minerals were still observed (such as partially dissolved ilmenite). It should be noted that such a protocol resembles those used to extract palynofacies. The samples thus prepared are therefore likely to contain solid organic fractions, in addition to pyrite. However, most of the $\mathrm{OM}$ is removed along with the clay minerals when the beakers are emptied, taking care not to lose the dense fractions (typically pyrite).

The samples were then observed using photonic and electronic microscopy (FEI Quanta 200 SEM equipped with a Quantax QX2 Roentec energy-dispersive X-ray spectroscopy system). This SEM study made it possible to observe the surface of (poly)framboids and even the interior of those that were fractured. This electron microscopic examination also ensured that OM fragments were not visible in the subsamples intended for elemental analysis. The analysis of the carbon content was carried out using a CHNS Thermo Flash EA pyrolyzer. Lastly, mineral identification was performed through X-ray diffraction (XRD) methods following the protocol by Bout-Roumazeilles et al. (1999). XRD was used to ensure that no $\mathrm{C}$-bearing phases could still be present before elemental analysis. 


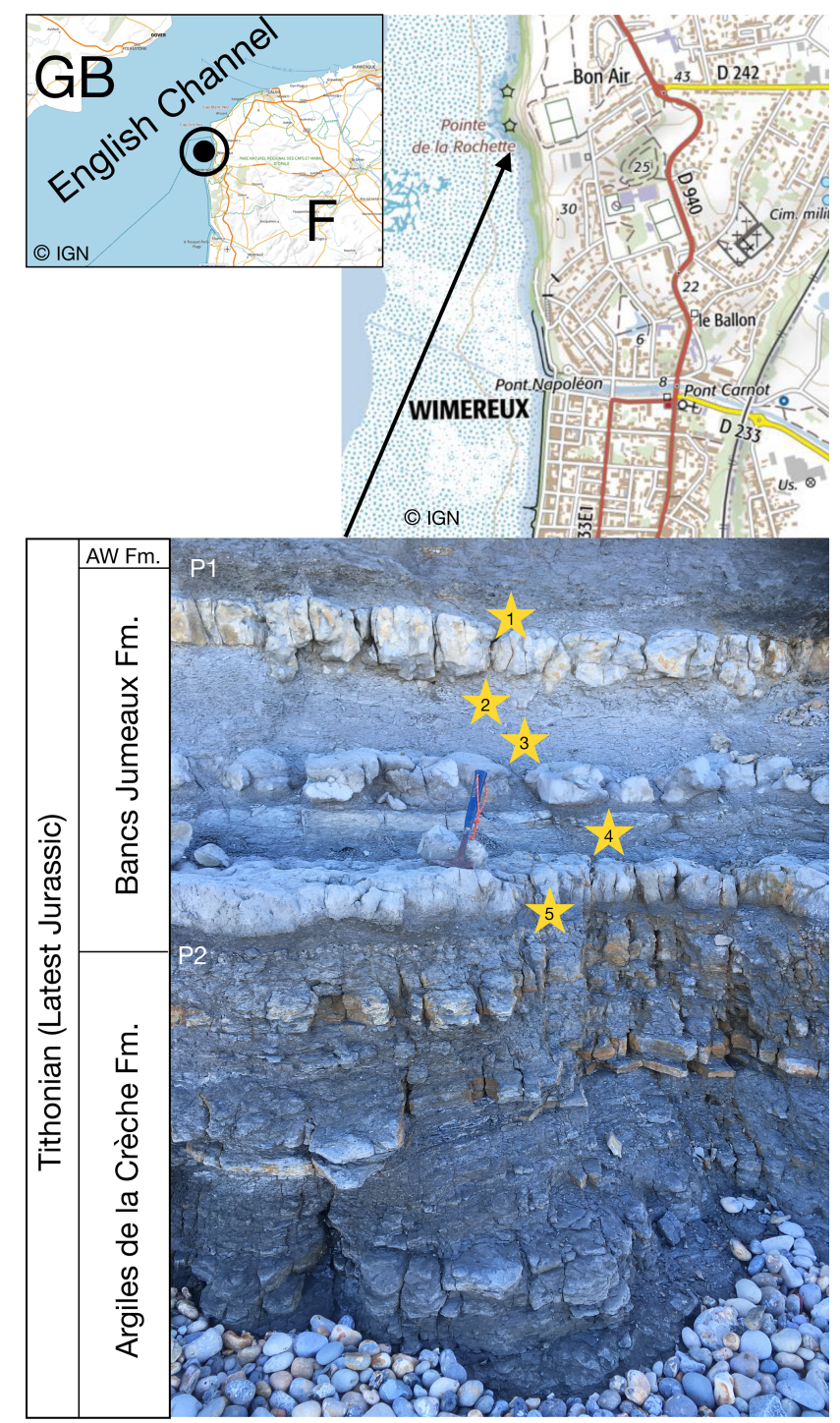

Figure 1. Location of the outcrop of the Bancs Jumeaux Fm. sampled here, north of Wimereux, at the place called "Pointe de la Rochette". The maps were drawn using the Institut Géographique National Géoportail. The Bancs Jumeaux Fm. is intercalated between the underlying Argiles de la Crèche Fm. and the overlying Argiles de Wimereux Fm. (AW Fm.).

\section{Results}

We observed a great diversity in the morphology and the surface of (poly)framboids, as evidenced by the images of Figs. 2 and 3. In particular, in each of the samples, we observed framboids where each elemental crystal was perforated, showing one or two orifices (Figs. 2 and 3). The individual perforated crystals have a size usually bracketed between 3 and $6 \mu \mathrm{m}$. Such framboids do not represent the majority of the (poly)framboids observed. It is remarkable that in some framboids the perforated crystals may have a geometric, sub-euhedral shape (Figs. 2 and 3). Finally, a few rare

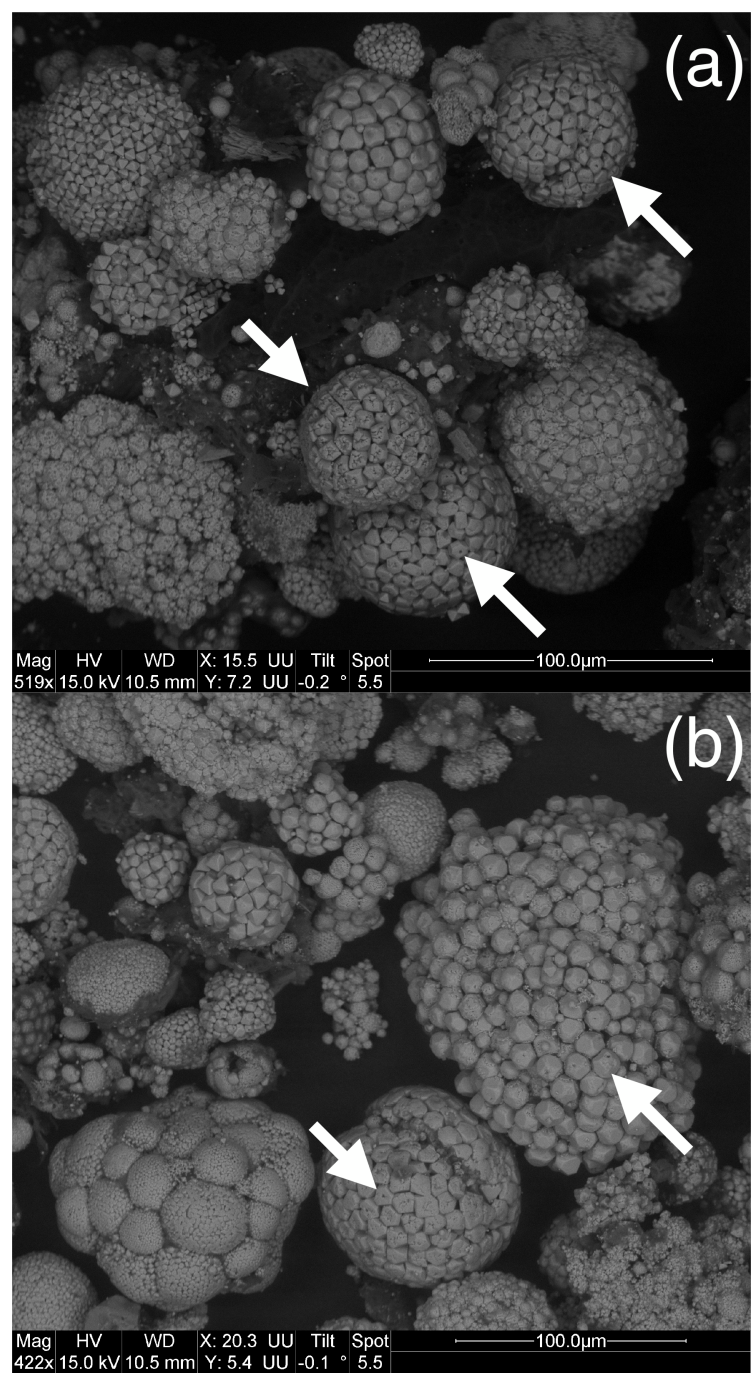

Figure 2. Images (a) and (b) illustrate the variety of framboids observed in the samples of the Bancs Jumeaux Fm. (marly interbeds). The arrows indicate framboids with individual grains showing orifices. Note that such grains tend to adopt euhedral morphologies.

framboids have shown that each elemental sphere is made of a very thin pyrite shell, filled with pyrite (Fig. 4a and b). The shells adopt a (sub-)euhedral form. Such a euhedral particulate grain (Fig. 4b), a little deeper into the framboid than the others, is intact, as if it had been protected, while the more exposed crystals appear to have been worn (perhaps during sample preparation). The morphology of this unworn grain does not suggest that the interior is different from the shell or that the shell is so thin.

The framboids yielding orifice-bearing microcrystals are in the same size range, and the perforated microcrystals also fall within a specific size range, close to $8 \mu \mathrm{m}$, as illustrated with Fig. 5a and b. Notably, Fig. 5a shows the many morphologies and sizes adopted by framboids and microcrystals as well, in a single rock sample; but from one sample 


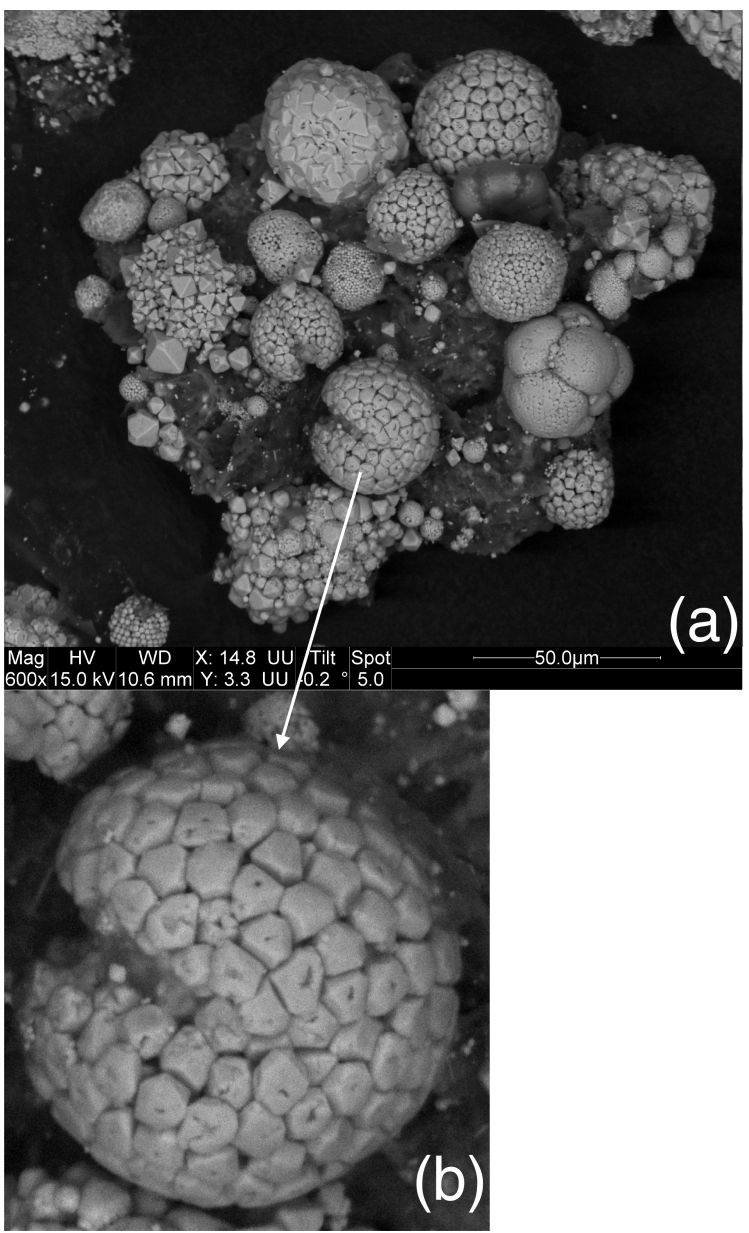

Figure 3. (a) A display of pyrite framboids showing the diversity of the morphologies and surfaces of the objects. (b) The macaroon shape with a slightly depressed equatorial groove is frequently observed in the Bancs Jumeaux Fm. (see Fig. 2b). This "macaroon" also yields individual grains bearing orifices.

to another, the perforated microcrystals and the corresponding framboids show rather uniform dimensions (white arrows in Fig. 5a and b). Elementary analyses of the samples show carbon contents of between $1.8 \%$ and $5.5 \%$ (Table 1). As reported in the "Materials and methods" section (Sect. 2), it cannot be excluded that ultrathin molecular layers could adsorb onto pyrite surfaces during sample preparation, even if the low $\mathrm{pH}$ did not favor such adsorptions. If that were the case, such small captures of OM could not account for the high $\mathrm{C}$ content of pyrite observed here.

\section{Interpretations}

The abundance of OM demonstrated in the framboids studied here is relatively strong. However, the samples, examined with the SEM before chemical analysis, did not show any organic particles. This therefore leads us to consider that $\mathrm{OM}$

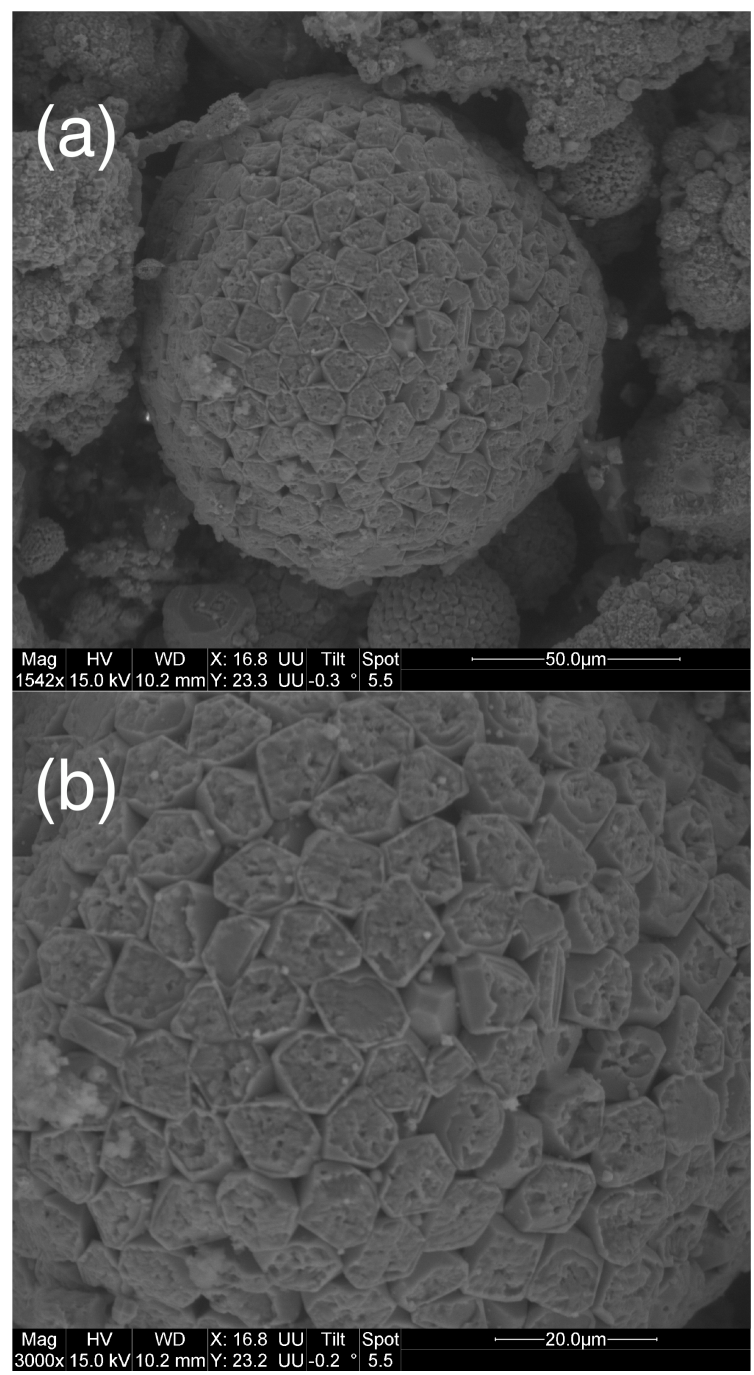

Figure 4. (a) Some rare framboids yield such organization depicted here, with a thin pyrite shell with (sub-)euhedral morphology, hosting fillings made up of pyrite. (b) Close-up view of (a).

Table 1. Carbon content of the five samples.

\begin{tabular}{lc}
\hline Sample & Carbon (wt \%) \\
\hline 1 & 2.9 \\
2 & 6.5 \\
3 & 2.8 \\
4 & 5.6 \\
5 & 2.8 \\
\hline
\end{tabular}

is contained within framboids. Even if some organic fragments could have been present among the framboids without being visible, that would not account for the high $\mathrm{C}$ contents. We infer that the most likely explanation for these high $\mathrm{C}$ levels lies in the presence of OM contained in individual grains of framboids or within framboids, between individual grains, without this being visible using the SEM. Wacey et 

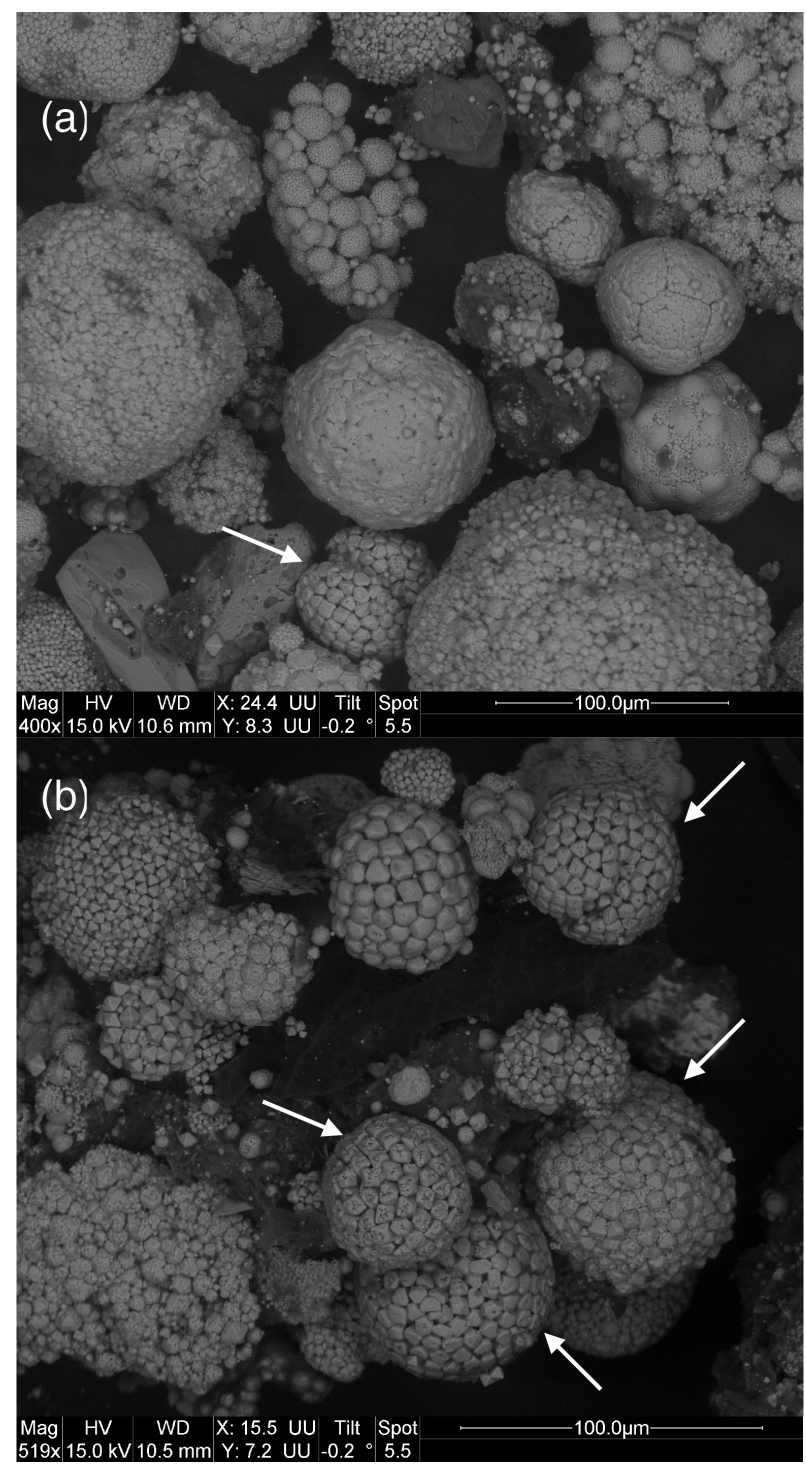

Figure 5. SEM images showing that the framboids yielding perforated microcrystals (a, white arrow) as well as the perforated microcrystals themselves fall in a rather narrow size range, compared to the other types of framboids observed in each rock sample (b).

al. (2015) and Gregory et al. (2019) observed the presence of OM between microcrystals; our SEM images show that there is empty pore space between the microcrystals where $\mathrm{OM}$ could nest. Our sample preparation using $\mathrm{HCl}$ digestion must have cleaned the outer part of the framboid from its $\mathrm{OM}$, but OM may still be present between microcrystals in the inner parts of the framboids.

However, identifying the presence of OM does not provide any information on its nature or its origin. We cannot know, at this point, whether it is bacterial biomass trapped in the framboids.
The presence of orifices in the elemental crystals that make up framboids suggests that these crystals may be hollow, or at least may have been so. The existence of hollow pyrite crystals was demonstrated by Cevales (1961), Butler (1994) and Ohfuji (2004), as reported by Rickard (2021). However, the hollow crystals illustrated in Rickard's book (Rickard, 2021, chap. 4, pp. 85-86) do not look like what we are seeing here. Those crystals show a perfect octahedral outer shape that could not be suspected to be empty. In addition, the outer shapes do not show orifices such as those we observed. Butler (1994) and Ohfuji (2004) believed that hollow crystals would result from abiotic crystal growth phenomena. However, the morphological differences between the crystals encountered by these authors and those illustrated in this work suggest that they are not comparable objects.

In contrast, there is a morphological convergence between what Castanier et al. (1999a, b) described regarding the calcification of living bacteria and what we observed. The perforated grains constituting some framboids are of a size compatible with that of bacteria, and they suggest the mineralization of spherical objects that would be covered with a thin coating of pyrite. The orifices observed could have allowed exchanges with the external milieu, essential for the (at least temporary) survival of the sulfate-reducing bacteria. In the same way as the calcareous cocoons observed by Castanier et al. (1999a) could recrystallize and adopt automorphic crystal shapes very quickly, pyrite cocoons may have adopted shapes typical of the pyrite cubic system during very early diagenesis but also during subsequent diagenesis.

Modern sulfate-reducing bacteria usually show long dimensions not exceeding $4 \mu \mathrm{m}$. Here the perforated microcrystals are typically close to $8 \mu \mathrm{m}$ in diameter. These dimensions are not much larger than the size of (modern) sulfate reducers and are compatible with a size being increased when the outer pyrite shell grows around bacteria. Castanier et al. (1999a) observed an increase in the size of the minerals caging their live carbonatogenic bacteria, compared to the size of the bacteria themselves.

Our hypothesis is not based solely on a transposition to pyrite of what Castanier et al. (1999a, b) observed by calcifying bacteria in vitro. Indeed, Picard et al. (2019) studied the interactions between the metabolism of sulfate-reducing bacteria and iron-sulfide minerals generated during their lifetime. These authors have shown the relative stability of organo-mineral interactions in anoxic environments. Picard et al. (2019) also underlined the action of sulfate-reducing bacteria in the effective association of iron sulfides (mackinawite/greigite) and OM over years and also that this association favors the protection of labile organic molecules from degradation. This view can be enlarged over geologic times, as encouraged by our results, suggesting the possible, longlasting association of $\mathrm{OM}$ and pyrite, on some occasions.

Even if the parallel that we make between the calcification observed by Castanier and her co-workers and the pyritization of bacteria hypothesized here was unfounded or erro- 
neous, the fact remains that our results highlight the significant presence of carbon (and therefore organic matter) associated with the framboids of the Bancs Jumeaux Fm.

\section{Conclusions}

The sole purpose of this brief communication is to provide observations that will fuel reflection on the presence of organic matter inside pyrite framboids. Of course, there is no question of considering this to be the only cause of formation of framboids, which can also appear under abiotic conditions and following several mechanisms. Furthermore, our work underlines the diversity of morphologies and sizes that can be observed among the framboids of a single rock sample. Our observations support the hypothesis that bacteria can become covered with a pyrite coating during their lifetime. Even if our hypothesis were true, we have no way of verifying that these are sulfate-reducing bacteria. To progress, we would need to be able to analyze the organic matter contained in framboids, e.g., releasing the molecules by laser ablation coupled to a spectrometer; perhaps direct framboid spectrometry would suffice (Fourier transform infrared spectroscopy). We can supply framboids from the Bancs Jumeaux Fm. to those who wish to continue this study. The final idea to retain from this preliminary work is that certain forms of pyrite appeared under conditions allowing the trapping of organic matter, whatever the origin of the latter. This means that sedimentary pyrite can represent an organic matter trap. As sedimentary pyrite is a very abundant mineral in recent or old sediments, such a trap can be significant, and this component of the carbon cycle deserves to be quantified.

Data availability. No data sets were used in this article.

Author contributions. NT charged himself with project design, sample collection, sample preparation, result interpretation, bibliography compliation and paper redaction. VBR charged herself with project design, sample collection, sample analysis and result interpretation. MD charged herself with sample preparation, sample analysis and result interpretation. SV charged herself with sample analysis and result interpretation. AB (master's student) charged himself with sample collection, sample preparation and result interpretation.

Competing interests. The contact author has declared that neither they nor their co-authors have any competing interests.

Disclaimer. Publisher's note: Copernicus Publications remains neutral with regard to jurisdictional claims in published maps and institutional affiliations.
Acknowledgements. We thank Monique Gentric for administration management and the Earth Science Department of the University of Lille for its help. Thanks to David Rickard for his long-lasting interest and for encouraging us to publish these results. Thanks to Jannick Ingrin and Carlos Rodriguez-Navarro, who accepted the idea to submit this preliminary work to the European Journal of Mineralogy, and to Lourdes Fernández Díaz, associate editor. The reviews by Daniel D. Gregory and the anonymous referee were constructive and helpful; merci!

Review statement. This paper was edited by Lourdes Fernández Díaz and reviewed by Daniel D. Gregory and one anonymous referee.

\section{References}

Baumgartner, R. J., Van Kranendonk, M. J., Wacey, D., Fiorentini, M. L., Saunders, M., Caruso, S., Pages, A., Homann, M., and Guagliardo, P.: Nanoporous pyrite and organic matter in 3.5-billion-year-old stromatolites record primordial life, Geology, 47, 1039-1043, https://doi.org/10.1130/G46365.1, 2019.

Bebié, J. and Schoonen, M. A. A.: Pyrite surface interaction with selected organic aqueous species under anoxic conditions, Geochem. Trans. 1, 47, https://doi.org/10.1186/1467-4866-1-47, 2000.

Berner, R. A.: Early Diagenesis: a Theoretical Approach, Princeton University Press, Princeton, USA, ISBN 0-691-08258-8, 1980.

Boetius, A., Ravenschlag, K., Schubert, C. J., Rickert, D., Widdel, F., Gieseke, A., Amann, R., Jørgensen, B. B., Witte, U., and Pfannkuche, O.: A marine microbial consortium apparently mediating anaerobic oxidation of methane, Nature 407, 623-626, 2000.

Bout-Roumazeilles, V., Cortijo, E., Labeyrie, L., and Debrabant, P.: Clay-mineral evidence of nepheloid layer contribution to the Heinrich layers in the Northwest Atlantic, Palaeogeogr. Palaeocl., 146, 211-228, 1999.

Braissant, O., Cailleau, G., Dupraz, C., and Verrecchia, E. P.: Bacterially induced mineralization of calcium carbonate in terrestrial environments: the role of exopolysaccharides and amino acids, J. Sediment. Res., 73, 485-490, 2003.

Burdige, D. J.: Geochemistry of Marine Sediments, Princeton University Press, Princeton, USA, ISBN 0-691-09506-X, 2006.

Butler, I. B.: Framboid formation, PhD thesis, University of Wales, Cardiff, UK, 434 pp., 1994.

Castanier, S., Le Métayer-Levrel, G., and Perthuisot, J.-P.: Cacarbonates precipitation and limestone genesis - the microbiogeologist point of view, Sediment. Geol., 126, 9-23, 1999a.

Castanier, S., Le Métayer-Levrel, G., and Perthuisot, J.-P.: Bacterial roles in the precipitation of carbonate minerals, in: Microbial Sediments, edited by: Riding, R., and Awramik, S., Springer, Berlin, Heidelberg, Germany, ISBN 978-3-540-61828-7, 1999 b.

Cevales, G.: Erzuntersuchungen im Emissionsmikroskop, Zeitschrift für Erzbergbau und Metallhüttenwesen, 14, 159-210, 1961.

Duverger, A., Berg, J. S., Busigny, V., Guyot, F., Bernard, S., and Miot, J.: Mechanisms of pyrite formation promoted by sulfate- 
reducing bacteria in pure culture, Front. Earth Sci., 8, 588310, https://doi.org/10.3389/feart.2020.588310, 2020.

Gregory, D. D., Mukherjee, I., Olson, S. L., Large, R. R., Danyushevsky, L. V., Stepanov, A. S., and Avila, J. N.: The formation mechanisms of sedimentary pyrite nodules determined by trace element and sulfur isotope microanalysis, Geochim. Cosmochim. Ac., 259, 53-68, 2019.

Gregory, D. D., Kovarik, L., Taylor, S. D., Perea, D. E., Owens, J. D., Atienza, N., and Lyons, T. W.: Nano-scale trace element zoning in pyrite framboids and implications for paleoproxy applications Geology, in press, 2022.

Han, G. Wen, S. Wang, H., and Feng, Q.: Interaction mechanism of tannic acid with pyrite surfaces and its response to flotation separation of chalcopyrite from pyrite in a low-alkaline medium, Journal of Materials Research and Technology, 9, 4421-4430, 2020.

Himmel H.-J., Kaschke, M. I., Harder, P., and Wöll, C.: Adsorption of organic monolayers on pyrite (FeS2)(100), Thin Solid Films, 284-285, 275-280, 1996.

Hinrichs, K.-U., Hayes, J., Sylva, S., Brewer, P., and DeLong, E.: Methane-consuming archaebacteria in marine sediments, Nature, 398, 802-805, 1999.

Jørgensen, B. B.: Mineralization of organic matter in the sea bed the role of sulphate reduction, Nature, 296, 643-645, 1982.

Large, D. J., Fortey, N. J., Milodowski, A. E., Christy, A. G., and Dodd, J.: Petrographic observations of iron, copper, and zinc sulfides in freshwater canal sediment, J. Sediment. Res., 71, 61-69, 2001.

Love, L. G. and Amstutz, G. C.: Review of microscopic pyrite from the Devonian Chattanooga Shale and Rammelsberg Banderz, Fortschritte des Mineralogie, 43, 277-309, 1966.

McLean, L. C. W., Tyliszczak, T., Gilbert, P. U. P. A., Zhou, D., Pray, T. J., Onstott, T. C., and Southam, G.: A high-resolution chemical and structural study of framboidal pyrite formed within a low-temperature bacterial biofilm, Geobiology, 6, 471-480, 2008.
Megonigal, J. P., Hines, M. E., and Visscher, P. T.: Anaerobic metabolism: linkages to trace gases and aerobic processes, in: Biogeochemistry, edited by: Schlessinger, W. H., Treatise on Geochemistry, edited by: Holland, H. D., Turekian, K. K., vol. 8, Elsevier, Pergamon, Oxford, pp. 317-424, ISBN 978-0-08098300-4, 2003.

Ohfuji, H.: Framboids, PhD Thesis, University of Wales, Cardiff, UK, 246 pp., 2004.

Picard, A., Gartman, A., Clarke, D. R., and Girguis, P. R.: Sulfatereducing bacteria influence the nucleation and growth of mackinawite and greigite, Geochim. Cosmochim. Ac., 220, 367-384, 2018.

Picard, A., Gartman, A., Cosmidis, J., Obst, M., Vidoudez, C., Clarke, D. R., and Girguis, P. R.: Authigenic metastable iron sulfide minerals preserve microbial organic carbon in anoxic environments, Chem. Geol., 530, 119343, https://doi.org/10.1016/j.chemgeo.2019.119343, 2019.

Rickard, D.: Sulfidic Sediments and Sedimentary Rocks, Developments in Sedimentology - Tome, 65, Elsevier, ISBN 978-0-44452989-3, 2012.

Rickard, D.: Framboids, Oxford University Press, Oxford, UK, https://doi.org/10.1093/oso/9780190080112.001.0001, 2021.

Schieber, J.: Sedimentary pyrite: A window into the microbial past, Geology, 30, 531-534, 2002.

Soetaert, K., Hofmann, A. F., Middelburg, J. J., Meysman, F. J. R., and Greenwood, J.: The effect of biogeochemical processes on pH, Mar. Chem., 105, 30-51, 2007.

Tribovillard, N., Lyons, T. W., Riboulleau, A., and BoutRoumazeilles, V.: A possible capture of molybdenum during early diagenesis of dysoxic sediments, B. Soc. Géol. Fr., 179, 3-12, 2008.

Wacey, D., Kilburn, M. R., Saunders, M., Cliff, J. B., Kong C., Liu, A. G., Matthews, J. J., and Brasier, M. D.: Uncovering framboidal pyrite biogenicity using nano-scale $\mathrm{CN}_{\text {org }}$ mapping, $\mathrm{Ge}-$ ology, 43, 27-31, 2015. 